\title{
The Shanghai Cooperation Organization in a Changing Central Asian Geopolitical Context
}

\author{
Rakhmatulla NURIMBETOV ${ }^{1 \oplus}$ - László VASA ${ }^{20}$
}

\begin{abstract}
The article discusses the initial role of the Shanghai Cooperation Organization (SCO) in Central Asia and the latest development trends, as well as possible scenarios for its transformation in the future, with a special focus on Central Asia. The enlargement of the SCO in 2017 enhanced its geopolitical weight and expanded opportunities for further multilateral cooperation. It has a chance to transform into the Eurasian organisation. Nevertheless, these perspectives remain unclear.
\end{abstract}

Keywords: Shanghai Cooperation Organization, Central Asia, Russia, China, geopolitics, regionalism, regional integration, transformation of the SCO

\section{Introduction}

This year marks the $20^{\text {th }}$ anniversary of the Shanghai Cooperation Organization (SCO). On 15 June 2001, the leaders of Russia, four Central Asian countries (Kazakhstan, Kyrgyzstan, Tajikistan, Uzbekistan), and China signed the Declaration on the Establishment of the Shanghai Cooperation Organization in Shanghai.

The SCO is a product of the new geopolitical situation in Central Asia as a result of the collapse of the bipolar system of international relations. It was formed on the basis of the Shanghai Five, which was formed in the 1990s to find solutions to border problems inherited from the Soviet Union to the Central Asian republics. Originally operating as an ad-hoc mechanism with the active support of China and Russia, this format has become a full-fledged regional organisation by the beginning of the $21^{\text {st }}$ century.

Until recently, the SCO's main focus was on Central Asia. However, the entry of Asia’s large but long-time rival countries into the SCO in 2017, such as India and Pakistan, as well as the ongoing geopolitical shifts in Eurasia, pose a number of serious challenges to the organisation.

National Coordinator of Uzbekistan for SCO Affairs, Ministry of Foreign Affairs, Uzbekistan; e-mail: sco@ mfa.uz

2 PhD, Professor, Széchenyi István University, Hungary; Senior Researcher, Chief Advisor, Institute for Foreign Affairs and Trade; e-mail: laszlo.vasa@ifat.hu 


\section{SCO profile: "Hegemonic Regionalism" or "New Model” of Regional Cooperation}

Prior to India's and Pakistan's accession to the SCO, experts used to describe the organisation as a platform for cooperation based on "competition and cooperation” (coopetion) between Beijing and Moscow in Central Asia. The approaches here are significantly different and contradict each other. This dichotomy is reflected by the critical views of Western scholars and experts on the organisation on the one hand, and by the assessment of the SCO as an example of a new regionalism by representatives of Chinese and Russian schools of political science, on the other hand.

Neo-realists in the West $^{3}$ see the emergence of the SCO as a "model of dominance in Central Asia” developed primarily by Russia and China. According to them, within the SCO, the two countries have shared "responsibilities" in the region: Russia is responsible for security and military-political issues, while China has chosen to develop economic cooperation. ${ }^{4}$ According to this approach, the SCO is a bloc formed against NATO and the Organization for Security and Cooperation in Europe (OSCE). ${ }^{5}$

According to another Western school - the normative approach, the SCO aims to "limit democracy and human rights and protect authoritarian political regimes”. ${ }^{6}$ For example, according to Roy Allison, a British expert, the nature of SCO became obvious in the early 2000s following the "Color Revolutions" supported by the United States and other Western countries. The British expert describes the organisation as a "security integration" project that seeks to ensure the security of Central Asia's ruling elites and the current political regime. ${ }^{7}$ So supporters of this view have described the SCO as a "club of authoritarian states whose goals and objectives are directed against Western and democratic values". ${ }^{8}$

Another group of Western scholars believes that the SCO is a clear example of "hegemonic regionalism". ${ }^{9}$ According to their theory, integration associations emerging outside the Western world are formed mainly under the "patronage” of the major powers in

3 Roy Allison, 'Protective Integration and Security Policy Coordination: Comparing the SCO and CSTO', The Chinese Journal of International Politics 11, no 3 (2018), 297-338.

4 Alyson J K Bailes et al., 'The Shanghai Cooperation Organization', SIPRI Policy Paper no 17 (2007); Stephen Aris, 'Shanghai Cooperation Organisation: An Anti-western Alignment?', CSS Analyses in Security Policy no 66 (2009); Nicola P Contessi, 'China, Russia and the Leadership of the SCO. A Tacit Deal Scenario', China and Eurasia Forum Quarterly 8, no 4 (2010), 101-123; Michał Lubina, Russia and China: A Political Marriage of Convenience - Stable and Successful (Opladen-Berlin-Toronto: Barbara Budrich Publishers, 2017).

5 Sean Roberts, The Shanghai Cooperation Organization: Is It Undermining U.S. Interests in Central Asia? Hearing before the Commission on Security and Cooperation in Europe, One Hundred Ninth Congress, second session, 26 September 2006.

6 Marcin Kaczmarski, ‘Non-western visions of regionalism: China’s New Silk Road and Russia’s Eurasian Economic Union’, International Affairs 93, no 6 (2017), 1357-1376.

7 Allison, 'Protective Integration and Security Policy Coordination: Comparing the SCO and CSTO', 298.

8 Anastassia Obydenkova and Alexander Libman, Autocratic and Democratic External Influences in PostSoviet Eurasia (Routledge, 2015).

9 James H Mittelman and Richard Falk, 'Global Hegemony and Regionalism', in The Globalization Syndrome - Transformation and Resistance, ed. by James H Mittelman (Princeton University Press, 2000). 
the region. Regional hegemons use such structures to strengthen their position in relations with other regions of the world and power centres. ${ }^{10}$

It needs to be highlighted that the views of Western researchers on the SCO, based on scepticism and concern, were formed in the late twentieth century and the first decade of the $21^{\text {st }}$ century. At the time, the United States and Europe were particularly concerned about the organisation's potential to become an alternative "centre of power" that could jeopardise the Western-led world order.

Russia was initially more optimistic about the SCO as a means of shaping a new security system with its participation in Central Asia. This issue is also widely discussed in the approaches of Russian researchers. ${ }^{11}$ At the heart of their views is the idea that the SCO is a mechanism for securing Russia's strategic interests in Central Asia. This includes not only the SCO's competitiveness with the United States and NATO, but also the need to strengthen the partnership between the SCO and other regional security mechanisms in the Russian-led region. ${ }^{12}$ Moscow has always been a supporter of the development of security and political-military cooperation within the SCO. An example of this is the Memorandum of Understanding on Cooperation and Interaction between the Regional Anti-Terrorism Structure (RATS) of SCO, the CIS Anti-Terrorism Center (ATC) and the Secretariat of the Collective Security Treaty Organization (CSTO), signed in 2018 at the initiative of the Russian Federation. ${ }^{13}$

Chinese researchers are very positive about the development of the SCO, its importance for China's foreign policy, its place in the processes in Central Asia and in the system of international relations in general.

First, their research provides a conceptual basis for Beijing's official position and strategy towards the SCO. In the early 2000s, Zhao outlined the following six priorities of China's strategy towards the SCO: 1. the fight against the "three evils" (terrorism, extremism and separatism); 2. to ensure the security of border areas; 3. to contribute to regional stability; 4 . participation in the economic development of the region; 5 . to prevent Central Asia from falling under the influence of states or military blocs hostile to China; 6. access to energy resources in the region. ${ }^{14}$

10 Louise Fawcett and Andrew Hurrell, Regionalism in World Politics: Regional Organization and International Order (Oxford University Press, 2015).

11 Dimitriy Vladimirovich Gordiyenko, 'Шанхайская Организация сотрудничества как площадка для диалогапо вопросам региональной безопасности’ [Shanghai Cooperation Organization as a Platform for Dialogue on Regional Security Issues], National Interests: Priorities and Security 37 (2015), 44-66; Yulia Nikitina, 'ОДКБ и ШОС как модели взаимодействия в сфере региональной безопасности' [CSTO and SCO as models of interaction in the field of regional security]. Индекс Безопасности 97, nо 2 (2011), 45-53; Denis Alekseevich Borisov, Эволюция политики безопасности Шанхайской организации сотрудничества: 1996-2010 г2 [The evolution of the security policy of the Shanghai Cooperation Organization: 1996-2010]. Candidate of Science (PhD) dissertation, Tomsk State University, Russia, 2011.

12 Nikitina, ‘ОДКБ и ШОС как модели взаимодействия в сфере региональной безопасности’ [CSTO and SCO as models of interaction in the field of regional security], 48.

13 Меморандум о взаимопонимании по вопросам сотрудничества и взаимодействия между РАТС ШОС, АТЦ СНГ и Секретариатом ОДКБ [Memorandum on mutual understanding on cooperation and interaction between the SCO RATS, the CIS ATC and the CSTO Secretariat], 28 May 2018.

14 Chao Xuashen, ‘Китай, Центральная Азия и Шанхайская организация сотрудничества' [China, Central Asia and the Shanghai Cooperation Organization], Carnegie Moscow Center Working Papers 5 (2005). 
Second, Chinese researchers note that the conceptual elements of China's foreign policy define the doctrinal and ideological foundations of the SCO, first and foremost in the SCO Charter, which defines the ideas and concepts of the struggle against the "Shanghai spirit" and "three evils". ${ }^{15}$ "The SCO was established at the same time with the implementation of socialist modernization and policy reforms in China. That is why its formation is directly linked to the development of China and changes in diplomacy ... The SCO is a discovery of Chinese diplomacy”, says Pan Dapen. ${ }^{16}$

Third, further developing the above views, in recent years there has been a significant increase in Chinese diplomatic and expert circles' attempts to interpret the SCO as a "new model” in international relations and to substantiate it scientifically. Wang Xiaoquan, another leading expert at the Chinese Academy of Social Sciences, believes that the SCO, based on the basic principles of the "Shanghai Spirit" (mutual trust, mutual benefit, equality, consultation, respect for cultural diversity, the desire for common development), is a unique international organisation that includes states from different civilisations and political systems. This, Wang assumes, allows promoting inclusive cooperation and "harmonious order" within the SCO, in contrast to other international structures. ${ }^{17}$

\section{SCO mission in Central Asia}

Despite the differences in the approaches listed above, there is no doubt that the SCO is a regional organisation initiated by China and Russia and supported by Central Asian countries. However, it raises the question of how much the SCO has contributed to the development of stability and cooperation in Central Asia, and how this is reflected.

This requires clarification of another conceptual issue. Is the SCO itself a real security organization? This again leads to the same dichotomy. A group of experts interprets it as a "guarantee of stability in Central Asia”. ${ }^{18}$ In particular, the former SCO Secretary General Rashid Alimov notes "despite the fact that the SCO is located in the immediate vicinity of global hotbeds of terrorism, extremism and separatism, the SCO has not allowed the region for which it is responsible to become a hotbed of instability, to fill the gap created here on the threshold of a new century by radical ideologies and extremists, to absorb false values". ${ }^{19}$ Other observers, mostly Western experts, say the SCO has failed to find a solution as a classic regional security organisation, which will mainly serve to ensure the

15 Pan Guang, “Что такое “шанхайский дух"' [What is "Shanghai spirit”], Central Internet portal of the Shanghai Cooperation Organization (SCO); Zhang Xin, 'Opinion: The undying importance of the 'Shanghai Spirit’, China Global Television Network, CGTN, 03 June 2018.

16 Pan Dapen, 'Роль ШОС во внешнеполитической стратегии Китая' [The role of the SCO in China’s foreign policy strategy], 01 October 2020.

17 Wang Xiaoquan, 'SCO: A new model for close, inclusive international relations', China Today Commentaries, 11 June 2018.

18 Van Chaotsin, ‘Дееспособность при сотрудничестве в области безопасности в рамках шос’ [Сарасіty in security cooperation within the SCO], Теория и Практика Общественного Развития [Theory and Practice of Social Development] 2 (2015), 54-59.

19 Rashid Alimov, Шанхайская организация сотрудничества: становление, развитие, перспективы [Shanghai Cooperation Organization: Formation, Development, Prospects] (Весь Мир [The Whole World] Publishing, 2017), 336. 
security of authoritarian regimes in Central Asia. ${ }^{20}$ As a clear example of the SCO's failure to become a real regional security tool, Western observers cite its "empty" position on the Afghan conflict. ${ }^{21}$ Although Afghanistan has observer status in the SCO and the issue is constantly discussed within the organisation, there is still no single "Afghan strategy" within the structure.

However, in our view, the SCO has never been, in essence, a classical security or military organisation.

First, a more comprehensive analysis of the SCO's contribution to strategic stability and security in Central Asia is needed. Sustainability and security are very broad concepts, covering not only the issues of ensuring the sovereignty and territorial integrity of the country, but also issues of economic development and social stability. It is this approach that allows for a full and objective disclosure of the organisation's stabilising role in the region.

Second, the main founding documents, the Shanghai Declaration and the Charter, show that the Organisation aims at "strengthening cooperation in the political, security, economic, cultural, humanitarian and other spheres of the SCO”. In other words, the founding states have not initially planned to create the SCO in the form of "collective security" or military-political alliance. In addition, in recent literature, the SCO has not been classified as a "collective security organisation” or "economic integration structure”, but as a trans-regional organisation with a new kind of universal agenda. ${ }^{22}$

Third, analysts who are increasingly critical of the SCO's role in Central Asia and its activities in general do not pay enough attention to the deep essence of the concept of the "Shanghai spirit" and its place in the life of the organisation. The "Shanghai spirit” embodies the following principles: "Mutual trust, mutual benefit, equality, mutual consultation, respect for cultural diversity, the pursuit of common development."

The practical application of these principles is of great importance for the Central Asian states. As Amit R Saxena, an Indian researcher, points out, the "Shanghai spirit" - the SCO's main doctrine - has created the principles of non-interference to internal affairs and the sovereignty of member states, created immunity for Central Asia from the threat of Russia and China. ${ }^{23}$ In turn, as the authors of the analytical document 'Regional organizations in Central Asia: peculiarities of cooperation, efficiency-related dilemmas’ pointed out, "despite the strong position of Moscow and Beijing, the governments of the Central Asian republics promote their interests, by "vetoing” the consideration of issues raised by the two large countries. As a result, projects that have been pushed forward by

20 Julie Boland, 'Ten Years of the Shanghai Cooperation Organization: A Lost Decade? A Partner for the U.S.?', The Brookings Institution, Federal Executive Fellows Policy Papers, 24 June 2011.

21 Richard Weitz, 'Afghanistan, not new members, will determine SCO’s relevance', World Politics Review, 14 July 2015.

22 Alimov, Шанхайская организация сотрудничества: глобальный профиль в международных отношениях [Shanghai Cooperation Organization: A Global Profile in International Relations], 144.

23 Amit R Saksena, 'Structural and policy problems prevent the SCO from being an effective Central Asian security organization’, The Diplomat, 25 July 2014. 
Russia and China, despite their superiority, have not been implemented due to a lack of support from the organization's Central Asian members". ${ }^{24}$

In what ways is the stabilising role of the SCO reflected in Central Asia? In our opinion:

First, the SCO prevented the establishment of a clear geopolitical dominance of a major external power centre in the region, thereby ensuring geopolitical balance and strategic stability in Central Asia. In particular, the SCO has ensured that Russia and China do not fall under the influence of the United States and NATO in the region, while the Central Asian states have pursued a multi-vector foreign policy, thereby balancing the interests of leading powers and gaining political, military and economic benefits.

Second, the organisation has been balancing the strategic interests of Russia and China in Central Asia, thereby ensuring their constructive cooperation. Despite the competitive interests between the two sides, Moscow and Beijing recognise the organisation as an important regional mechanism for communication. From Russia's point of view, the SCO serves China to act in accordance with the rules of the "multilateral game" in Central Asia and, consequently, to curb its ambitions in the region. For the PRC, the establishment of the organisation "legitimised" its influence in Central Asia, that is, gave it an institutional form. ${ }^{25}$ This has created a very important image for Beijing in its efforts to dispel accusations of pursuing an "expansionist" policy toward the region. The SCO has also acted as a "buffer" in the way of competition between the two major powers, namely in resolving disputes between them peacefully and diplomatically, and directing their competition to finding mutually beneficial solutions for regional stability. Thus, the competition between Russia and the PRC has not reached the level of conflict in the region, which could jeopardise the security, sovereignty and territorial integrity of the states here. This is a very important factor if we take into account the potential conflicts in Central Asia over the remaining border issues, ethnic and water resources, as well as threats around the region (the ongoing situation in Afghanistan, terrorism and extremism, the importance of the "Uyghur” factor for China). Therefore, its success in ensuring the balance of power is considered by many experts critical of the SCO as the organisation's "most productive political effectiveness". ${ }^{26}$ Some observers say the SCO has served to ease political, military and economic pressure from Russia, which sees the region as its "sphere of influence" for Central Asia. At the same time, China's policy of non-interference in the internal affairs of Central Asian states and its economic assistance have helped Kazakhstan, Kyrgyzstan, Tajikistan and Uzbekistan to contain Russia's influence. This means that the Central Asian states have learned to make effective use of the "competitive cooperation" of their two major neighbours, and the SCO platform has played a very important role in this.

Third, Beijing's “balancing” role with Moscow has strengthened Central Asia’s ability to cooperate with the United States and NATO in the military sphere, despite its more liberal foreign policy and its membership in the Russian-led CSTO. Such a "positive"

24 Marlen Laruel and Sebastian Peyruz, 'Региональные организации в Центральном союзе: характеристики взаимодействий, дилеммы эффективности’ [Regional organisations in the Central Union: Characteristics of interactions, efficiency dilemmas]. University of Central Asia Report Series 10 (2013).

25 Zhao Huasheng, 'China's View of and Expectations from the Shanghai Cooperation Organization', Asian Survey 53, no 3 (2013), 436-460.

26 Bailes et al., ‘The Shanghai Cooperation Organization', 11. 
contribution of China to the independent foreign policy of the Central Asian states through the SCO can be seen in the fact that they do not support Russia's interference in the internal affairs of Georgia and Ukraine. ${ }^{27}$ Observers say that with the indirect help of China, Central Asian states have not openly supported Moscow's aggressive policy in the post-Soviet space. ${ }^{28}$

Fourth, given that the Central Asian republics have not been able to form a "purely regional” integration organisation, the SCO has accomplished this task to some extent. The SCO has been and remains a platform for leaders, ministers, security officials and even representatives of economic blocs and experts from Kyrgyzstan, Kazakhstan, Tajikistan and Uzbekistan to discuss issues of multilateral regional cooperation, even taking into account the participation of Russia and China.

Thus, assessing the SCO's role in ensuring stability and security in Central Asia on the basis of whether it has been formed as a "collective security organisation" or an “integration structure” does not fully explain the organisation's role in regional stability and geopolitical processes in general.

\section{Eying on broader Eurasia?}

After India and Pakistan became full members in 2017, the SCO entered a new stage. But its previous essence and profile has changed.

At first glance, the SCO has evolved from a "pure" regional organisation to the largest Eurasian interstate body. Currently, the total area of its member states is more than 34 million square kilometres. This means $60 \%$ of the Eurasian region. The total population of the SCO countries is more than 3 billion, which is about half of the world's population. In addition, four members of the organisation (Russia, China, Pakistan and India) are states with nuclear weapons and an important position in international relations. But in the post-2017 period, the potential for such a large partnership remains untapped in practice. Cooperation in the fields of economy, transport and logistics, investment and finance, promising economic sectors and implementation of infrastructure projects has not reached a qualitatively new level. In recent years, member states' aspirations in this regard are largely limited to adoption of programs of general nature and declarative documents.

In fact, the slowdown of the cooperation in the SCO began to manifest itself before its expansion in 2017. For some ten years, Beijing has been promoting two economic initiatives: the establishment of the SCO Development Bank and the Development Fund, as well as the creation of a Free Trade Area (FTA) within the organisation. Russia has opposed these Chinese attempts to institutionalise economic and financial cooperation within the organisation. In response, Moscow has pushed its Eurasian Economic Community (EAEC) and its subsequent "Greater Eurasia” concept as a top goal of its reinvented geopolitics

27 Stephen Aris, 'Shanghai Cooperation Organization: Mapping multilateralism in transition no. 2', International Peace Institute, IPI, December 2013.

28 Marc Lanteigne, 'Russia, China and the Shanghai Cooperation Organization: Diverging Security Interests and the Crimea Effect', in Russia's Turn to the East. Global Reordering, ed. by Helge Blakkisrud and Elana Wilson-Rowe (Palgrave MacMillan, 2018). 
towards Eurasia. The reason for such a strategic shift was not only the deterioration of Moscow's relations with Europe, but also its fear on the growing influence of China in Central Asia. In turn, by 2013, there was a radical shift in the global strategy of the PRC, which was partly due to the situation in the SCO. In the belief that Moscow would allow the potential transformation of the SCO into the bloc with an economic nature. "The Shanghai Cooperation Organization Faces a Strategic Choice” China's new leader, Xi Jinping, announced the One Belt, One Road (OBOR) initiative. China has decided to create a mechanism to strengthen its influence in Central Asia and Eurasia in general, without the "assistance" of the SCO.

In fact, launching of the OBOR embodied China's Eurasian grand strategy without having a deal with Moscow at multilateral formats (e.g. the SCO). In this way, Beijing's dream of turning the SCO into a mechanism of economic integration has lost its meaning. It seems the SCO has fulfilled its main mission within Beijing's strategy towards Central Asia, at least for the coming years. As the OBOR has been realising in a most assertive way, the SCO remains in its shadow. In fact, the OBOR is essentially a project based on China's previous strategy towards the SCO. In this sense, it is a continuation of Beijing's initiatives aimed at creating financial institutions and international transport corridors within the SCO, but for some reason did not materialise. In particular, the principles of "mutual consultations”, “mutual benefit”, “common development desire” declared by Beijing's OBOR language derive from the "Shanghai spirit”, which is the cornerstone of the SCO's doctrine.

In the future, China's influence in Asia and in the world in general is expected to increase, which raises the question of what role the SCO may play in its strategy. For now, there is no doubt that the OBOR is the main foreign policy priority for Beijing. In general, both Russia and China see the SCO more as a "support mechanism" in the implementation of their regional order concepts - “Greater Eurasia” and the OBOR respectively.

There are some speculations that the Moscow-Beijing tandem may become a "trio" by the addition of Delhi. The RIC (Russia-India-China) is actively promoted mainly by Moscow, as it wants to "curb” rising Chinese influence in Eurasia. In fact, this was the main reason why Russia openly lobbied Delhi to join the SCO. In this sense, what is India's approach to the SCO and its future? Is Delhi ready to participate in building the future of the organisation within the RIC format? If the RIC would develop with success, chances of these three major powers to improve their relations within the SCO will increase. As such, it could strengthen the organisation itself, too. However, if the "trio" fails, would it have a negative impact on the SCO future?

In the near future, the following developments may hinder the effective operation of the RIC.

First, it seems that the territorial dispute between China and India will remain as a "ticking bomb", which can turn into a grave diplomatic and even military conflict at any time. The military clashes in 2020 in Ladakh province revealed a potential for such a scenario.

Second, as a result of the further deterioration of "West-Russia" and "West-China" relations, the close connections of Moscow and Beijing may worry India and cause its distancing from the RIC format. 
Third, India's growing competition with China in Southeast Asia may chill the dialogue between Beijing and Delhi and even indirectly affect India's relations with Russia.

Thus, the question of the RIC's role as a potential "pillar" for the future of the SCO remains open. It is clear that the other members of the SCO - Central Asian countries and Pakistan - will certainly affect the future development of the organisation, too. However, unlike the "big three", they do not seek to establish their own geopolitical concepts in the region.

\section{The Future of the SCO}

Regardless in what way the SCO will develop in coming years, it will face the dilemma of expansion. The organisation claims its openness to the membership of other Eurasian countries and some of them have been knocking on the door for some years. For example, Iran and Afghanistan, among others.

However, current permanent members are well aware that in light of the worsening of the international situation and further aggravation of the global economy due to the Covid-19 pandemic, it is superfluous to discuss this topic. Moreover, the full adaptation of India and Pakistan to the organisation is also a time-consuming process. For this reason, it is hardly worth expecting that the SCO will accept new members in the near future. As such, we do not consider the expansion the factor of an influence on the development trajectory of the organisation in the short term.

On the other hand, the growing number of member states without addressing the institutional gaps may lead the SCO to fragmentation, provoking the emergence of "tactical alliances" within itself. This experience may be applied to other universal international organisations, as well. For example, in the SCO case, unresolved bilateral issues among the members could lead to a scenario like that. As mentioned earlier, border issues between India and Pakistan, China and India remain pending. Disagreements between Russia and China, China and India over strategic topics are also unlikely to disappear any time soon.

Thus, marking its $20^{\text {th }}$ anniversary, the SCO is facing serious strategic challenges. It needs to address tough issues: from internal institutional developments to strategic competition among major members. Its member states', primarily Russia, China and India's, common answer to the question of whether this mechanism could play a key role in shaping a future fate of the organisation.

\section{References}

Alimov, Rashid, Шанхайская организация сотрудничества: становление, развитие, перспективы [Shanghai Cooperation Organization: Formation, Development, Prospects]. Весь Мир [The Whole World] Publishing, 2017. Online: www.vesmirbooks.ru/books/ catalog/intrelations/3322/ 
Allison, Roy, 'Protective Integration and Security Policy Coordination: Comparing the SCO and CSTO’. The Chinese Journal of International Politics 11, no 3 (2018), 297-338. Online: https://doi.org/10.1093/cjip/poy008

Aris, Stephen, 'Shanghai Cooperation Organisation: An Anti-western Alignment?' CSS Analyses in Security Policy no 66 (2009). Online: https://css.ethz.ch/content/dam/ethz/specialinterest/gess/cis/center-for-securities-studies/pdfs/CSS-Analyses-66.pdf

Aris, Stephen, 'Shanghai Cooperation Organization: Mapping multilateralism in transition no. 2’. International Peace Institute, IPI, December 2013. Online: www.ipinst.org/wpcontent/uploads/publications/ipi_e_pub_shanghai_cooperation.pdf

Bailes, Alyson J K, Pál Dunay, Pan Guang and Mikhail Troitskiy, 'The Shanghai Cooperation Organization'. SIPRI Policy Paper no 17 (2007). Online: www.sipri.org/sites/default/files/ files/PP/SIPRIPP17.pdf

Boland, Julie, 'Ten Years of the Shanghai Cooperation Organization: A Lost Decade? A Partner for the U.S.?’ The Brookings Institution, Federal Executive Fellows Policy Papers, 24 June 2011. Online: www.brookings.edu/research/ten-years-of-the-shanghai-cooperationorganization-a-lost-decade-a-partner-for-the-united-states/

Borisov, Denis Alekseevich, Эволюция политики безопасности Шанхайской организации сотрудничества: 1996-2010 гг [The evolution of the security policy of the Shanghai Cooperation Organization: 1996-2010]. Candidate of Science (PhD) dissertation, Tomsk State University, Russia, 2011. Online: www.dissercat.com/content/evolyutsiya-politikibezopasnosti-shankhaiskoi-organizatsii-sotrudnichestva

Chaotsin, Van, 'Дееспособность при сотрудничестве в области безопасности в рамках шос' [Capacity in security cooperation within the SCO]. Теория и Практика Общественного Развития [Theory and Practice of Social Development] 2 (2015), 54-59.

Contessi, Nicola P, 'China, Russia and the Leadership of the SCO. A Tacit Deal Scenario'. China and Eurasia Forum Quarterly 8, no 4 (2010), 101-123.

Dapen, Pan, ‘Роль ШОС во внешнеполитической стратегии Китая’ [The role of the SCO in China’s foreign policy strategy], 01 October 2020. Online: https://russiancouncil.ru/ analytics-and-comments/analytics/rol-shos-vo-vneshnepoliticheskoy-strategii-kitaya/

Fawcett, Louise and Andrew Hurrell, Regionalism in World Politics: Regional Organization and International Order. Oxford University Press, 2015. Online: https://docenti.unimc. it/u1.chelatidirar/teaching/2015/14864/files/reading-materials-on-regionalism/historicalperspectives

Gordiyenko, Dimitriy Vladimirovich, ‘Шанхайская Организация сотрудничества как площадка для диалогапо вопросам региональной безопасности’ [Shanghai Cooperation Organization as a Platform for Dialogue on Regional Security Issues]. National Interests: Priorities and Security 37 (2015), 44-66. Online: http://213.226.126.9/ ni/2015/ni37/ni3715-44.pdf

Guang, Pan, ‘Что такое “шанхайский дух”' [What is “Shanghai spirit”]. Central Internet portal of the Shanghai Cooperation Organization (SCO). Online: www.infoshos.ru/ru/?idn=3296

Huasheng, Zhao, 'China's View of and Expectations from the Shanghai Cooperation Organization', Asian Survey 53 no 3 (2013), 436-460. Online: https://doi.org/10.1525/ as.2013.53.3.436 
Kaczmarski, Marcin, ‘Non-western visions of regionalism: China’s New Silk Road and Russia’s Eurasian Economic Union’. International Affairs 93, no 6 (2017), 1357-1376. Online: https://doi.org/10.1093/ia/iix182

Lanteigne, Marc, 'Russia, China and the Shanghai Cooperation Organization: Diverging Security Interests and the Crimea Effect', in Russia's Turn to the East. Global Reordering, ed. by Helge Blakkisrud and Elana Wilson-Rowe. Palgrave MacMillan, 2018. Online: https://doi.org/10.1007/978-3-319-69790-1_7

Laruel, Marlen and Sebastian Peyruz, 'Региональные организации в Центральном союзе: характеристики взаимодействий, дилеммы эффективности’ [Regional organisations in the Central Union: Characteristics of interactions, efficiency dilemmas]. University of Central Asia Report Series 10 (2013). Online: www.ucentralasia.org/Content/downloads/ UCA-IPPA-WP-10-RegionalOrganizations-Rus.pdf

Lubina, Michał, Russia and China: A Political Marriage of Convenience - Stable and Successful. Opladen-Berlin-Toronto: Barbara Budrich Publishers, 2017. Online: https:// doi.org/10.2307/j.ctvdf0314

Меморандум о взаимопонимании по вопросам сотрудничества и взаимодействия между РАТС ШОС, АТЦ СНГ и Секретариатом ОДКБ [Memorandum on mutual understanding on cooperation and interaction between the SCO RATS, the CIS ATC and the CSTO Secretariat], 28 May 2018. Online: https://antiterror.odkb-csto.org/int_organizations/ RATS\%20SHOS-ATC\%20SNG-CSTO/memorandum/

Mittelman, James H and Richard Falk, 'Global Hegemony and Regionalism', in The Globalization Syndrome - Transformation and Resistance, ed. by James H Mittelman. Princeton University Press, 2000. Online: https://doi.org/10.1515/9781400823697

Nikitina, Yulia, 'ОДКБ и ШОС как модели взаимодействия в сфере региональной безопасности' [CSTO and SCO as models of interaction in the field of regional security]. Индекс Безопасности 97, nо 2 (2011), 45-53. Online: www.pircenter.org/media/content/ files/0/13406397580.pdf

Obydenkova, Anastassia and Alexander Libman, Autocratic and Democratic External Influences in Post-Soviet Eurasia. Routledge, 2015. Online: https://doi.org/10.4324/9781315568492

Roberts, Sean, The Shanghai Cooperation Organization: Is It Undermining U.S. Interests in Central Asia? Hearing before the Commission on Security and Cooperation in Europe, One Hundred Ninth Congress, second session, 26 September 2006. Online: www.csce. gov/sites/helsinkicommission.house.gov/files/The\%20Shanghai\%20Cooperation\%20 Organization\%20Is\%20it\%20Undermining\%20U.S.\%20Interests\%20in\%20Central\%20 Asia.pdf

Saksena, Amit R, 'Structural and policy problems prevent the SCO from being an effective Central Asian security organization’. The Diplomat, 25 July 2014. Online: https:// thediplomat.com/2014/07/the-shanghai-cooperation-organization-and-central-asiansecurity/

Weitz, Richard, 'Afghanistan, not new members, will determine SCO’s relevance', World Politics Review, 14 July 2015. Online: www.worldpoliticsreview.com/articles/16223/ afghanistan-not-new-members-will-determine-sco-s-relevance

Xuashen, Chao, 'Китай, Центральная Азия и Шанхайская организация сотрудничества [China, Central Asia and the Shanghai Cooperation Organization]. Carnegie Moscow 
Rakhmatulla NURIMBETOV - László VASA: The Shanghai Cooperation Organization...

Center Working Papers 5 (2005). Online: www.studmed.ru/view/huashen-ch-kitaycentralnaya-aziya-i-shanhayskaya-organizaciya-sotrudnichestva_258ae3b8b8a.html

Xin, Zhang, 'Opinion: The undying importance of the 'Shanghai Spirit'.' China

Global Television Network, CGTN, 03 June 2018. Online: https://news.cgtn.com/ news/3d3d774d3263444f77457a6333566d54/share_p.html

Xiaoquan, Wang, 'SCO: A new model for close, inclusive international relations'. China Today Commentaries, 11 June 2018. Online: www.chinatoday.com.cn/ctenglish/2018/ hotspots/2018sh/2/201806/t20180611_800132521.html 